\title{
General Anesthesia
}

\section{Identification of independent risk factors for fentanyl-induced cough}

\author{
[L'identification de facteurs de risque indépendants pour la toux induite par le
}

fentanyl]

Tsutomu Oshima MD, Yoshiko Kasuya MD, Yasuhisa Okumura MD, Tatsuo Murakami MD, Shuji Dohi MD

Purpose: To determine how the probability of fentanyl-induced cough is affected by patient characteristics and/or anesthetic technique.

Methods: We analyzed data from a cohort of I,3II adult patients undergoing elective surgery under general anesthesia, accompanied by iv fentanyl. The following data were collected: patient demographics, history of cigarette smoking, presence of bronchial asthma or chronic obstructive pulmonary disease, administration of angiotensin converting enzyme inhibitors; and anesthetic technique, including: preanesthetic anxiolytic medication, prior use of atropine, epidural lidocaine, a priming dose of vecuronium, and the dose of iv fentanyl. Associations between individual variables in the clinical evaluation model and the likelihood of fentanyl-induced cough were characterized by calculating odds ratios. Multiple logistic regression analysis was used to examine the independent contribution of each variable while controlling for all variables.

Results: Fentanyl-induced cough was independently associated with the following: aging, cigarette smoking, a prior epidural injection of lidocaine, and a priming dose of vecuronium. Fentanyl-induced cough was unaffected by gender, the presence of either bronchial asthma or chronic obstructive pulmonary disease, or prior use of atropine.

Conclusions: Fentanyl-induced cough may be suppressed by aging, cigarette smoking, prior epidural injection of lidocaine, or a priming dose of vecuronium. These findings may allow insights into the mechanism of this phenomenon, thereby leading to its prevention.
Objectif : Déterminer comment la probabilité de toux induite par le fentanyl est modifiée par les caractéristiques du patient et/ou la technique anesthésique.

Méthode: Nous avons analysé les données sur I 31 I patients adultes qui ont subi une opération réglée sous anesthésie générale accompagnée de fentanyl iv. Nous avons noté les données suivantes: les caractéristiques des patients, les antécédents de tabagisme, la présence d'asthme bronchique ou de maladie pulmonaire obstructive chronique, l'administration d'inhibiteurs de l'enzyme de conversion de l'angiotensine. La technique anesthésique comprenait : la médication préanesthésique anxiolytique, l'usage antérieur d'atropine, l'anesthésie péridurale avec lidocaïne, la dose d'amorçage de vécuronium et la dose iv de fentanyl. Les associations entre les variables individuelles dans le modèle d'évaluation clinique et la probabilité de toux induite par le fentanyl ont été définies par le calcul du risque relatif. Une analyse de régression logistique multifactorielle a servi à vérifier la contribution indépendante de chaque variable tout en contrôlant pour toutes les variables.

Résultats : La toux induite par le fentanyl a été indépendamment associée aux données suivantes: l'âge, le tabagisme, une injection péridurale antérieure de lidocaïne et une dose d'amorçage de vécuronium. La toux induite par le fentanyl n'était pas modifiée par le sexe du patient, l'asthme bronchique ou la maladie pulmonaire obstructive chronique ou l'usage antérieure d'atropine.

Conclusion: La toux induite par le fentanyl peut être supprimée par le vieillissement, le tabagisme, une injection péridurale antérieure de lidocaïne ou une dose d'amorçage de vécuronium. Ces résultats peuvent donner un aperçu du mécanisme de ce phénomène et conduire à sa prévention.

From the Department of Anesthesia, Gifu University School of Medicine, Gifu-City, Gifu, Japan.

Address correspondence to: Dr. Tsutomu Oshima, Department of Anesthesia, Teikyo University School of Medicine Ichihara Hospital, 3426-3 Anesaki, Ichihara, Chiba 299-0111, Japan. Phone: 81-436-62-1211; Fax: 81-436-62-2621;

E-mail: oshimat@med.teikyo-u.ac.jp

This study was supported in part by Grant-in-Aid 17591624 from Japan Society for the Promotion of Science.

Accepted for publication January 18, 2006.

Revision accepted February 25, 2006.

Competing interests: None declared. 
A

LTHOUGH opioid agonists are known to posess antitussive activity, $i v$ administration of fentanyl, a synthetic opioid, paradoxically induces cough. ${ }^{1-5}$ Fentanyl-induced cough may be explosive at times, and may require immediate therapeutic intervention when it undesirably increases intracranial, intraocular or intraabdominal pressures. ${ }^{3-5}$ Although the mechanism of fentanyl-induced cough is unclear, several measures by which this phenomenon can be avoided have been demonstrated during induction of general anesthesia. ${ }^{4-5}$

Cough is the result of mechanical or chemical stimulation of sensory receptors within the respiratory tract, the afferent impulses from these receptors activating a putative brainstem cough centre. ${ }^{6}$ In addition to angiotensin converting enzyme (ACE) inhibitors, ${ }^{7}$ fentanyl is regarded as a valuable tussive medication among the systemically administered drugs available for humans. Therefore, exploration into the mechanism of fentanyl-induced cough may provide insights into the physiology of the cough reflexes in humans, while leading to development of the preventive methods for this phenomenon in the clinical setting.

In the present study, we carried out an epidemiologic investigation of the likelihood of fentanylinduced cough occurring during induction of general anesthesia. Our aim was, by comparing the present findings with the previous data accumulated from the conventional cough models elicited by inhalation of capsaicin, ${ }^{8}$ citric acid, ${ }^{9}$ or distilled water aerosol, ${ }^{10}$ or by oral administration of ACE inhibitors, ${ }^{7}$ to allow insights into the mechanism of fentanyl-induced cough.

\section{Methods}

After Institutional Review Board approval, the patient population consisted of 1,311 consenting patients referred for elective surgery under general anesthesia at the Gifu University Hospital from March 2001 to November 2002. This study is a secondary historical cohort analysis of data extracted from the database maintained by one of the authors. Exclusion criteria included an age less than $20 \mathrm{yr}$, absence of preanesthetic anxiolytic medication, administration of lidocaine or antitussive drugs such as codeine, dextromethorphan, or baclofen within the previous week, and persistent symptomatic coughing that was difficult to differentiate from fentanyl-induced cough.

The database included each patient's age, sex, height, and weight. Other data included history of cigarette smoking, the existence of bronchial asthma or chronic obstructive pulmonary disease (COPD), and administration of ACE inhibitors. With respect to anesthetic technique, the type of anxiolytic drug given as preanesthetic medication (benzodiazepines, clonidine, or hydroxyzine), prior use of atropine, epidural catheterization and injection of lidocaine, a priming dose of vecuronium, and the dose of intravenously injected fentanyl were recorded. As the only clinical endpoint, one observer continuously assessed the occurrence of cough responses after iv injection of fentanyl as a bolus in a peripheral $i v$ infusion. The one-minute data collection period was followed by termination of this observation.

\section{Statistical analysis}

To compare the group data as demographic or anesthesia-related findings between patient groups with and without fentanyl-induced cough, categorical data were analyzed using the Pearson Chi-square tests with Yates' correction or Fisher's exact probability test, as appropriate. Continuous data were analyzed by means of a one-way analysis of variance. With all tests, a $P$ value $<0.05$ was considered statistically different. Group data are presented as the mean \pm $\mathrm{SD}$, number, or percentage. The relative magnitudes of the associations between individual variables as demographic or anesthesia-related findings, and the likelihood of fentanyl-induced cough, were compared by calculating crude odds ratios (OR). The precision of the estimated OR was assessed by the use of $95 \%$ confidence intervals (CI), the association between a specific variable and fentanyl-induced cough being considered significant unless the CI included one. The second step in the analysis involved use of a multivariable logistic regression model containing all candidate variables. The final model was used to examine the independent contribution made by each variable while controlling for all variables, and it resulted in an adjusted OR and a calculated $95 \%$ CI. To evaluate the discrimination and calibration for the final model, the c-statistic and the Hosmer-Lemeshow goodness of fit Chi-square were calculated, respectively. Furthermore, to indicate the relative contribution of each variable to the final model, the likelihood Chi-square value for the predictors was presented. The statistics program used for the analysis was SPSS $11.5 \mathrm{~J}$ for Windows (SPSS Japan Inc., Tokyo, Japan).

\section{Results}

Of the 1,311 patients, 120 exhibited vigorous cough attacks within the first $20 \mathrm{sec}$ after $i v$ administration of fentanyl. Consideration of the demographic characteristics of the patients with and without fentanyl-induced cough revealed that the group showing fentanyl-induced cough had a lower age, lower per- 
TABLE I Demographic characteristics and anesthesia-related findings of patients with or without fentanyl-induced cough

\begin{tabular}{lllc}
\hline Demographic characteristics & Patients with FC $(n=120)$ & Patients without FC $(n=1,191)$ & $P$ values \\
\hline Age $(\mathrm{yr})$ & $48.3 \pm 18.5$ & $56.2 \pm 16.5$ & $<0.001$ \\
Male / female & $48 / 72$ & $592 / 599$ & 0.045 \\
Height $(\mathrm{cm})$ & $159.4 \pm 9.2$ & $158.9 \pm 9.5$ & 0.654 \\
Weight $(\mathrm{kg})$ & $55.4 \pm 12.3$ & $57.3 \pm 12.2$ & 0.113 \\
Cigarette smoking (\%) & 21.7 & 42.4 & $<0.001$ \\
Bronchial asthma or COPD (\%) & 2.5 & 6.5 & 0.107 \\
Premedication (benzodiazepines / clonidine / hydroxyzine) & $85 / 21 / 14$ & $577 / 274 / 340$ & $<0.001$ \\
Use of atropine (\%) & 23.3 & 32.8 & 0.040 \\
Epidural injection of lidocaine (\%) & 35.8 & 47.7 & 0.016 \\
A priming dose of vecuronium $(\%)$ & 35.0 & 44.3 & 0.053 \\
Fentanyl dose per weight $\left(\mu \mathrm{g} \cdot \mathrm{kg}^{-1}\right)$ & $2.3 \pm 0.8$ & $2.1 \pm 0.7$ & 0.042 \\
\hline
\end{tabular}

$\mathrm{FC}=$ fentanyl-induced cough; $\mathrm{ACE}=$ angiotensin converting enzyme; $\mathrm{COPD}=$ chronic obstructive pulmonary disease.

TABLE II Crude and adjusted association between possible risk factors and fentanyl-induced cough

\begin{tabular}{|c|c|c|c|c|c|c|}
\hline Possible risk factors & & $n(1,311)$ & $F C(\%)$ & $\begin{array}{l}\text { Crude OR } \\
(95 \% \text { CI) }\end{array}$ & $\begin{array}{l}\text { Adjusted OR } \\
(95 \% C I)\end{array}$ & $\begin{array}{l}\text { Likelihood } \\
\text { Chi-square } \\
\text { (Degree of } \\
\text { freedom) }\end{array}$ \\
\hline $\begin{array}{l}\text { Age } \\
(\mathrm{yr})\end{array}$ & & & & $\begin{array}{l}0.97 \\
(0.96-0.98)\end{array}$ & $\begin{array}{l}0.98 \\
(0.97-0.99)\end{array}$ & $15.5(1)$ \\
\hline \multirow[t]{2}{*}{ Sex } & Female & 671 & 10.7 & $\begin{array}{l}1.5 \\
(1.0-2.2)\end{array}$ & $\begin{array}{l}1.0 \\
(0.66-1.6)\end{array}$ & $0.005(1)$ \\
\hline & Male & 640 & 7.5 & & & \\
\hline \multirow[t]{2}{*}{$\begin{array}{l}\text { Cigarette } \\
\text { Smoking }\end{array}$} & Present & 531 & 4.9 & $\begin{array}{l}0.38 \\
(0.24-0.59)\end{array}$ & $\begin{array}{l}0.42 \\
(0.26-0.70)\end{array}$ & $12.3(1)$ \\
\hline & Absent & 780 & 12.1 & & & \\
\hline \multirow[t]{2}{*}{ Asthma or COPD } & Present & 80 & 3.8 & $\begin{array}{l}0.38 \\
(0.12-1.2)\end{array}$ & $\begin{array}{l}0.49 \\
(0.15-3.1)\end{array}$ & $1.6(1)$ \\
\hline & Absent & 1,231 & 9.5 & & & \\
\hline \multirow[t]{2}{*}{$\begin{array}{l}\text { ACE } \\
\text { Inhibitor }\end{array}$} & Present & 69 & 10.1 & $\begin{array}{l}1.1 \\
(0.50-2.5)\end{array}$ & $\begin{array}{l}1.3 \\
(0.57-3.1)\end{array}$ & $0.43(1)$ \\
\hline & Absent & 1,242 & 9.1 & & & \\
\hline \multirow[t]{3}{*}{ Pre-medication } & Hydroxyzine & 354 & 4.0 & $\begin{array}{l}0.28 \\
(0.16-0.50)\end{array}$ & $\begin{array}{l}0.24 \\
(0.11-0.51)\end{array}$ & $18.1(2)$ \\
\hline & Clonidine & 295 & 7.1 & $\begin{array}{l}0.52 \\
(0.32-0.86)\end{array}$ & $\begin{array}{l}0.57 \\
(0.34-0.97)\end{array}$ & \\
\hline & Benzodiazepines & 662 & 12.8 & & & \\
\hline \multirow[t]{2}{*}{ Atropine } & Present & 419 & 6.7 & $\begin{array}{l}0.62 \\
(0.40-0.97)\end{array}$ & $\begin{array}{l}1.2 \\
(0.64-2.3)\end{array}$ & $0.35(1)$ \\
\hline & Absent & 892 & 10.3 & & & \\
\hline Epidural & Present & 611 & 7.0 & 0.61 & 0.64 & $4.5(1)$ \\
\hline lidocaine & Absent & 700 & 11.0 & $(0.42-0.91)$ & $(0.42-0.97)$ & \\
\hline \multirow[t]{2}{*}{ Vecuronium } & Present & 570 & 7.4 & $\begin{array}{l}0.68 \\
(0.46-1.0)\end{array}$ & $\begin{array}{l}0.61 \\
(0.40-0.93)\end{array}$ & $5.4(1)$ \\
\hline & Absent & 741 & 10.5 & & & \\
\hline $\begin{array}{l}\text { Fentanyl dose } \\
\left(\mu \mathrm{kg} \mathrm{k}^{-1}\right)\end{array}$ & $\begin{array}{l}\geq 3 \\
<3\end{array}$ & $\begin{array}{l}179 \\
1,132 \\
\end{array}$ & $\begin{array}{l}13.4 \\
8.5 \\
\end{array}$ & $\begin{array}{l}1.7 \\
(1.0-2.7)\end{array}$ & $\begin{array}{l}1.4 \\
(0.86-2.4)\end{array}$ & $1.8(1)$ \\
\hline
\end{tabular}

$\mathrm{FC}=$ fentanyl-induced cough: $\mathrm{OR}=$ odds ratios; $\mathrm{CI}=$ confidence intervals: $\mathrm{ACE}=$ angiotensin converting enzyme; $\mathrm{COPD}=$ chronic obstructive pulmonary disease. 
centage of males, and a lower percentage of cigarette smokers (Table I). With respect to anesthetic factors, the group experiencing cough contained a higher percentage of patients who received benzodiazepine premedication, a lower percentage who had received atropine, and a lower percentage receiving epidural lidocaine; moreover, the former group had received a higher dose of fentanyl (Table I).

Table II displays (a) the number of patients found to have each demographic and anesthesia-related risk factor, as well as the percentage exhibiting fentanylinduced cough, (b) the crude OR and 95\% CI for each factor, and (c) the adjusted OR and the likelihood Chi-square value for each demographic and anesthesia-related possible risk factor (when adjusted for all variables in the model). The results exhibited by (b) crude OR were similar to those shown in Table I. However, the results obtained from (c) the adjusted OR were found to differ from these results as follows: a younger age, being a non-smoker, premedication with benzodiazepine, absence of epidural lidocaine, and absence of a priming dose of vecuronium were shown to be significant independent risk factors for the development of fentanyl-induced cough. Conversely, increased age, cigarette smoking, epidural lidocaine, and a priming dose of vecuronium were all associated with a decreased risk for fentanyl-induced cough. When given as anxiolytic premedication, hydroxyzine and clonidine each reduced the risk for fentanylinduced cough, as compared with benzodiazepine.

For the final model with all the independent variables, the c-statistic was 0.726 , and the HosmerLemeshow goodness of fit Chi-square value was 3.11 with $8^{\circ}$ of freedom. The observed significance level for this Chi-square value was 0.927 . Therefore, we do not reject the null hypothesis that there is no difference between the observed and predicted values. This model appeared to fit the data reasonably well.

\section{Discussion}

Our study shows that significant independent risk factors for the development of fentanyl-induced cough include a young age and absence of cigarette smoking, and, amongst anesthetic factors, the absence of epidurally administered lidocaine, and the absence of a priming dose of vecuronium.

These results differ from those shown in Tables I and II (b), which suggest that the predisposing factors for fentanyl-induced cough also include female gender, no prior administration of atropine, and a higher dose of fentanyl while excluding the absence of a priming dose of vecuronium. This study is a secondary historical cohort analysis of data obtained from our database. Use of a multiple logistic regression model allowed calculation of adjusted OR and 95\% CI so as to assess the independent contribution made by each candidate variable, while controlling for all candidates. As predisposing factors for fentanyl-induced cough, multivariable logistic analysis excluded female gender, no prior administration of atropine, and a higher dose of fentanyl, while also including the absence of a priming dose of vecuronium.

Several experimental cough models have been proposed: cough elicited by inhalation of capsaicin,${ }^{8}$ citric acid, ${ }^{9}$ or distilled water aerosol, ${ }^{10}$ or by oral administration of ACE inhibitors. ${ }^{7}$ The present findings need to be compared with the previous data accumulated from these conventional cough models. Firstly, we found that aging was associated with suppression of fentanyl-induced cough. This finding is supported by a decrease in the number of rapidly adapting stretch receptors with aging in dogs, ${ }^{11}$ although in humans the capsaicin cough threshold has been shown to be similar among different age groups of the same sex. ${ }^{12}$ Secondly, a cigarette smoking-induced inhibition of fentanyl-induced cough is consistent with the increase in the capsaicin cough threshold in smokers. ${ }^{13}$ Thirdly, the antitussive effect of epidurally administered lidocaine may be attributed to the systemic effects of this local anesthetic., 5 , Since use of a capsaicin cough challenge has demonstrated that cough-reflex sensitivity is preserved after cervical spinal cord injury, ${ }^{15}$ an epidural anesthesia-induced sensory and motor blockade is unlikely to contribute to a suppression of fentanyl-induced cough. Fourthly, the effects of nondepolarizing neuromuscular blocking drugs, including vecuronium, on cough threshold, remain to be established. Lastly, a hydroxyzine-induced reduction in the probability of fentanyl-induced cough is supported by the efficacy of the first generation antihistamines against postnasal drip syndrome, one of the major causes of persistently troublesome cough. ${ }^{16}$ Moreover, histamine release may be involved in the onset of fentanyl-induced cough. ${ }^{4}$ A clonidine-induced suppression of fentanyl-induced cough is inconsistent with a previous report that the inhaled-capsaicin cough threshold is not affected by oral administration of clonidine. ${ }^{17}$ Further controlled studies with placebo in humans are needed to elucidate these problems.

Several promising demographic and anesthesiarelated factors were found to be unrelated to the probability of fentanyl-induced cough. Firstly, no gender difference in the probability of fentanyl-induced cough was observed in this study, although female gender has previously been reported to increase capsaicin cough sensitivity. ${ }^{9,18}$ Secondly, there was 
no influence of bronchial asthma or COPD on the probability of fentanyl-induced cough. This finding is inconsistent with clinical data suggesting a hyperreactive response to tussive stimuli such as capsaicin in these pathologic conditions. ${ }^{19}$ These differences could reflect the use of different tussive drugs, differing patterns of symptoms, differences in disease severity, or alleviating effects of therapeutic drugs such as $\beta 2$ adrenergic agonists and corticosteroids on the cough response, ${ }^{4}$ whether elicited by fentanyl or capsaicin. Lastly, an antitussive effect of atropine was excluded by the multiple logistic regression analysis carried out in this study, a result supported by data previously obtained in humans and animals. ${ }^{20}$

Apart from fentanyl, ACE inhibitors are the only medications widely known to provoke cough attacks amongst the systemically administered drugs available for humans. ${ }^{7}$ ACE inhibitors presumably cause cough by preventing the breakdown of endogenous tachykinins or bradykinin, which in turn stimulate rapidly adapting stretch receptors within the airway. ${ }^{6}$ Given this proposed mechanism of ACE inhibitor-induced cough, we hypothesize that intravenously administered fentanyl may provoke cough by transiently stimulating pulmonary C-fibre receptors, which in turn release tachykinin, thereby indirectly activating rapidly adapting stretch receptors. Alternative hypotheses include sudden adduction of vocal cords or supraglottic obstruction by soft tissues secondary to fentanyl-induced muscle rigidity, and histamine release. Verification of these hypotheses regarding the mechanism of fentanyl-induced cough awaits the results of further studies. On the other hand, the present findings also suggest that a young, non-smoker may represent a high-risk patient for fentanyl-induced cough, and that both a priming dose of vecuronium and systemic administration of lidocaine may be recommended to prevent fentanyl-induced cough during induction of general anesthesia. This study is the first to demonstrate the preventive efficacy of a priming dose of vecuronium for fentanyl-induced cough, although iv lidocaine has been shown recently to suppress fentanyl-induced cough in a prospective, randomized controlled study. ${ }^{5}$ Further clinical trials examining fentanyl-induced cough, focusing on selective influencing factors, may provide new insights into the mechanism of fentanyl-induced cough in humans, thereby developing the means by which this phenomenon can be prevented in the clinical setting.

In conclusion, the probability of fentanyl-induced cough is decreased by aging, cigarette smoking, epidural administration of lidocaine, and a priming dose of vecuronium. There is no effect by gender, the pres- ence of either bronchial asthma or COPD, or prior use of atropine in this survey population.

\section{References}

1 Böhrer H, Fleischer F, Werning P. Tussive effect of a fentanyl bolus administered through a central venous catheter. Anaesthesia 1990; 45: 18-21.

2 Phua WT, Teh BT, Jong W, Lee TL, Tweed WA. Tussive effect of a fentanyl bolus. Can J Anaesth 1991; 38: 330-4.

3 Tweed WA, Dakin D. Explosive coughing after fentanyl injection. Anesth Analg 2001; 92: 1442-3.

4 Agarwal A, Azim A, Ambesh S, et al. Sabutamol, beclomethasone or sodium chromoglycate suppress coughing induced by iv fentanyl. Can J Anesth 2003; 50: 297-300.

5 Pandey CK, Raza M, Ranjan R, et al. Intravenous lidocaine suppresses fentanyl-induced coughing: a double-blind, prospective, randomized placebo-controlled study. Anesth Analg 2004; 99: 1696-8.

6 Widdicombe JG. Neurophysiology of the cough reflex. Eur Respir J 1995; 8: 1193-1202.

7 Israili $Z H$, Hall WD. Cough and angioneurotic edema associated with angiotensin-converting enzyme inhibitor therapy. A review of the literature and pathophysiology. Ann Intern Med 1992; 117: 234-42.

8 Fuller RW, Dixon CM, Barnes PJ. Bronchoconstrictor response to inhaled capsaicin in humans. J Appl Physiol 1985; 58: 1080-4.

9 Bickerman HA, Barach AL, Drimmer F. The experimental production of cough in human subjects induced by citric acid aerosols. Preliminary studies on the evaluation of antitussive agents. Am J Med Sci 1954; 228: 156-63.

10 Sheppard D, Rizk NW, Boushey HA, Bethel RA. Mechanism of cough and bronchoconstriction induced by distilled water aerosol. Am Rev Respir Dis 1983; 127: 691-4.

11 Pontoppidan H, Beecher HK. Progressive loss of protective reflexes in the airway with the advance of age. JAMA 1960; 174: 2209-13.

12 Fujimura $M$, Kasahara $K$, Kamio $\Upsilon$, Naruse $M$, Hashimoto T, Matsuda T. Female gender as a determinant of cough threshold to inhaled capsaicin. Eur Respir J 1996; 9: 1624-6.

13 Dicpinigaitis $P V$. Cough reflex sensitivity in cigarette smokers. Chest 2003; 123: 685-8.

14 Christensen V, Ladegaard-Pedersen HJ, Skovsted P. Intravenous lidocaine as a suppressant of persistent cough caused by bronchoscopy. Acta Anaesthesiol Scand Suppl 1978; 67: 84-6.

15 Dicpinigaitis PV, Grimm DR, Lesser M. Cough reflex sensitivity in subjects with cervical spinal cord injury. 
Am J Respir Crit Care Med 1999; 159: 1660-2.

16 Irwin RS, Madison JM. The persistently troublesome cough. Am J Respir Crit Care Med 2002; 165: 146974.

17 O'Connell F, Thomas VE, Fuller RW, Pride NB, Karlsson JA. Effect of clonidine on induced cough and bronchoconstriction in guinea pigs and healthy humans. J Appl Physiol 1994; 76: 1082-7.

18 Dicpinigaitis, $P V$, Rauf $K$. The influence of gender on cough reflex sensitivity. Chest 1998; 113: 1319-21.

19 Doberty MJ, Mister R, Pearson MG, Calverley PM.

Capsaicin responsiveness and cough in asthma and chronic obstructive pulmonary disease. Thorax 2000; 55: 643-9.

20 Karlsson JA, Sant'Ambrogio G, Widdicombe J. Afferent neural pathways in cough and reflex bronchoconstriction. J Appl Physiol 1988; 65: 1007-23. 